\title{
SHARIA ECONOMIC LEGAL CONTRIBUTION OF ECONOMIC DEVELOPMENT IN INDONESIA
}

\author{
Mukharom \\ B. Rini Heryanti \\ Dhian Indah Astanti \\ Havis Aravik
}

\begin{abstract}
As part of the teachings of Islam, Islamic economic law is important to be taken into account in the formation of national law. Factually Islamic economic law is a living law (the living law) in Indonesian society since the entry of Islam into the archipelago. This research was conducted analytically descriptively, that is a study that described and described the conditions and facts in detail, systematically and thoroughly about the contribution of sharia economic law in economic development in Indonesia and the approach used was juridical empirical, so that the data used in this study namely primary data and secondary data. Primary data is collected by interviewing the subjects determined by the researchers, namely the authorized institutions / agencies, while secondary data is obtained from literature, legislation and related documents. The problem in this study is how the contribution of Islamic economic law to economic development in Indonesia. The results of his research are 1. Islamic economics as a surefire solution to poverty alleviation, this is very appropriate because the poor are not seen as a lazy party, but as a party that does not get access to a better life. Here in lies the difference between the Islamic and conventional economic systems. The Islamic economic system does not aim to accumulate as much wealth as possible. But, how a better life can be achieved together, the meaning is mutual help in the good between those who have excess property against those who need these assets. 2 . The efforts to positivate the Islamic economy itself have actually been going on for a long time and this needs to be supported. 3. One of the problems now faced by the Islamic finance industry in Indonesia is the availability of quality human resources. The continued development of the Islamic finance and banking industry is driving the need for quality human resources. Economics is an integral part of Islamic teachings, and therefore Islamic economics will be realized only if Islamic teachings are fully believed and implemented. Islamic economics studies the economic behavior of individuals who are consciously guided by the teachings of Islam, the Koran and the Sunnah in solving the economic problems they face.
\end{abstract}

Keywords: Economy, Sharia, Positivation, Contribution.

\section{INTRODUCTION}

Islamic economics is not a new discourse in the social and scientific world. It is a reality that continues to present itself to perfection amidst the diversity of conventional social and economic systems based on secular materialism. It is also a scientific reality that always reveals itself among the constellations of social sciences which are also based on secularism and even atheism. In both streams, Islamic economics represents a new force that is forming itself to become a mature and independent system and discourse in scientific reasoning. Its presence is not only an answer to the injustice of the contemporary socio-economic system, but also as a crystallization of intellectual efforts that have lasted very long in the history of the Muslims. ${ }^{1}$

Stretching the Islamic economic system in Indonesia can be said to be a bit late compared to other Muslim countries. Around the 90s, Islamic banking instruments emerged in Indonesia with Bank Muamalat as the first Islamic Bank. Whereas in neighboring countries like Malaysia, those years have shown the development of Islamic banking which is quite satisfying.

${ }^{1}$ Said Sa'ad Marathon, Ekonomi Islam Di Tengah Krisis Ekonomi Global, Maktabah Ar-Riyadh, Jakarta, 2007, hlm. 1 
Meanwhile in subsequent developments, the existence of Islamic economics has been able to establish itself parallel to economies that are not based on sharia / conventional economics. For this reason, the government is promoting sharia economics which needs to get attention wherein the development of the sharia economic system has grown rapidly. With such a rapid development of Islamic economy in Indonesia becomes a barometer that the Indonesian people are very welcoming of the development of the Islamic economy. But this does not rule out the possibility of problems occurring in the operation of Islamic economics.

One common misperception about the Islamic economic system is that this system is a "union" or "middle ground" between the capitalist and socialist economic systems. Such a view was initially unavoidable because: First, the idea of the Islamic economic system began to be conveyed by Muslim thinkers in the midst of the ideological battle of capitalism versus socialism. Secondly, coincidentally, some of the core ideas of Islamic economics contain similarities to the core ideas that already exist in the capitalist economic system or the socialist economic system, so that the core ideas of the Islamic economy that are conveyed are considered to be no more than the results of "capital" of the capitalist economic system or the socialist economic system .

Efforts to shape national law continue to the present day, although it has not been entirely successful. The government itself is very careful to finalize the draft national law, it seems less serious. Even legal experts do not seem to agree on the profile of national law. As a result of the nation's journey to live in the Dutch colonial legal system, the thoughts of legal experts in formulating Indonesian national law are still heavily influenced by Dutch law. Although the conception of national law is identified as a law with a core of customary law and law that lives in the community, but cannot be separated from the influence of the conception of Dutch law. ${ }^{2}$ The formation of national law certainly cannot only depart from the conception of western law (specifically the Dutch heritage). There are Islamic laws that have long been practiced by Muslims. Likewise, there is a customary law that has long been established and maintained in society. To realize national law must not ignore the existence of both.

The birth of a number of legislative devices which became the foundation of the development of the Islamic economy, as Law Number 23 of 1999 concerning the National Banking System which permits the operation of the Islamic banking system, Act Number 38 of 1999 concerning Zakat, Act Number 41 of 2004 concerning Endowments, Act Number 19 of 2008 concerning State Sharia Securities, Act Number 21 of 2008 concerning Sharia Banking. But this is not enough, especially considering that Government Regulations that describe these laws do not yet exist, so regulations, such as zakat, have not yet been realized at the operational level. This also happens to financial institutions, because the Islamic financial system is characteristically different from the conventional financial system, there are some specificities which cannot be equated so that the use of conventional legal frameworks becomes inadequate. For this reason, a compilation of Islamic economic/financial laws that are mutually agreed upon needs to be used as a reference and approved by the state.

As part of the teachings of Islam, Islamic economic law is important to be taken into account in the formation of national law. Factually Islamic economic law is a living law (the living law) in Indonesian society since the entry of Islam into the archipelago. How Islamic economic law can contribute to development in Indonesia, that is what the author will discuss in this study.

${ }^{2}$ Khudzaifah Dimyati, Teorisasi Hukum (Studi Perkembangan Pemikiran Hukum di Indonesia 1945-1990), Yogyakarta: Genta Publishing, 2010, hlm. 158-160 


\section{Approach Method}

\section{RESEARCH METHODS}

Research aims to reveal the truth systematically, methodologically and consistently. Through the research process, an analysis and constructive analysis of the data collected and processed is carried out. ${ }^{3}$ Research is basically "an effort to dilute" and not merely to observe closely an object that is easily held in the hand. In other words, research is an educational search effort.

Methodology is something that is very important for research and can be said that the methodology is an absolute element that must be present in research activities, for that in a study, researchers need to use the right method because there is in one scientific work first depends on the method used. ${ }^{4}$ While Abdullah Kelib said the research method is one form of applying scientific methods in order to solve problems, the development of science and the search for truth which is done systematically, planned, and follows scientific concepts. ${ }^{5}$

The main problem in this study is the contribution of Islamic economic law to economic development in Indonesia. In this regard, the approach used in this study is an Empirical approach. Empirical legal research is looking at the law not only as a set of normative rules or what is the text of the law (law in the book), but also see how the law interacts with the community (law in action). Or in other words to find out the gap between reality (das sain) as it should be (das sollen) and how to overcome a difficulty. ${ }^{6}$ The reason for using this approach is because the research studied is related to the contribution of Islamic economic law to economic development in Indonesia.

\section{Data Source}

In a study generally distinguished between data obtained directly from the public and library materials. Sources of data directly obtained from the public are called primary data, while data sources derived from library materials are usually called secondary data. ${ }^{7}$

The primary and secondary legal materials examined are as follows:

1. Primary legal material, namely binding legal material, including:

a. Sharia economic law.

b. Legal sources regarding other laws and regulations related to the above research.

c. Books that discuss sharia economics and its contribution to economic development in Indonesia.

2. Secondary legal materials include:

a. Writings or opinions of legal experts regarding sharia economics.

b. Writings or opinions of legal experts regarding the contribution of Islamic economic law.

3. Tertiary legal materials that provide a deeper explanation of primary and secondary legal materials include:

a. Indonesian Encyclopedia

b. Legal Dictionary

c. English-Indonesian dictionary

d. Share legal magazines and journals

However, primary data is still needed to complete the study above. The primary data include:

${ }^{3}$ Soerjono Soekamto, Sri Marmudji, Penelitian Hukum Normatif : Suatu Tinjauan Singkat, Jakarta: PT. Raja Grafindo Persada, 2004, hlm.1

${ }^{4}$ Murseh Mursanef, Pedoman Membuat Skripsi, Jakarta:Haji Mas Agung, 1981, hlm. 31

${ }^{5}$ Abdullah Kelib, Metode Penelitian Fiqh dan Hukum Sekuler'dalam Majalah Masalah-Masalah Hukum, FH Undip No.5/1995, hlm. 5 dari pendapat Suharsini Harikunto, Prosedur Penelitian (satu pendekatan praktek), Jakarta: Rieneka Cipta, 1993, hlm. 12.

${ }^{6}$ Bustanudin Agus, Pengembangan Ilmu-Ilmu Sosial Studi Bidang Antara Pandangan Ilmiah Dan Ajaran Islam, Jakarta: Gema Insani, 1999, hlm. 71.

7 Soerjono Soekanto dan Sri Marmudji, Penelitian Hukum Normatif Suatu Tinjauan Singkat, Jakarta: PT Radja Grafindo Persada, 2004, hlm.21. 
a. Interviews with Islamic economic practitioners.

b. Interviews with experts in Islamic economic law.

\section{Data Collection Technique}

All data collected both secondary data and primary data in general are analyzed using descriptive methods. In accordance with the method used, the analysis used is as follows:

a. The first stage, basing on a doctrinal approach. At this stage researchers mainly conducted an inventory. Against the contribution of Islamic economic law to economic development in Indonesia. In this case the collection of all the principles or rules associated with the problem are carried out, and then organized into a comprehensive system, after previously carried out a collection of all the principles and rules that have been collected.

b. The second stage, basing on non-doctrinal research. The analysis is carried out using descriptive analysis method.

\section{Data Analysis}

Based on the problem formulation and research objectives, the data analysis was carried out qualitatively. To support this, empirical studies are needed, so that data analysis is more comparative. The method used is the inductive method, then constructing data/facts.

\section{RESULTS}

\section{Contribution of Sharia Economic Law to Economic Development in Indonesia.}

The international economic system in which the banking system is the most important subsystem, as well as the national economic system. In addition, a large Muslim population can be a potential customer of the Islamic financial industry and can support the creation of bright economic conditions, and is supported by abundant natural resources that can be used as an underlying transaction of the Islamic financial industry. In carrying out economic activities, humans as members of society need a pattern or rules that are the same as community members in other regions. This is needed to provide convenience and fairness in transactions, usually based on local knowledge and traditions and the mutual agreement of both parties.

National Development aims to create a just and prosperous society that is evenly material and spiritual based on the Pancasila and the 1945 Constitution in the Republic of Indonesia, an independent Republic of Indonesia, sovereignty, unity, and sovereignty of the people in an atmosphere of national life that is safe, peaceful, orderly and dynamic in an environment of free, friendly, orderly and peaceful world relations. The provisions of Article 33 of the 1945 Constitution (Amendment IV), outline that:

1. The economy is structured as a joint effort based on the principle of kinship;

2. Production which is important for the state and which controls the lives of many people is controlled by the state;

3. The earth, water and natural resources contained therein are controlled by the state and used for the greatest prosperity of the people;

The national economy is based on economic democracy with the principles of togetherness, fair efficiency, sustainability, environmentally friendly, independent, and by maintaining a balance of progress and national economic unity. This constitutes a constitutional duty that the economy must be structured, not allowed to be organized and develop without order. The economic and / or licensing regulatory system needs to play a role in such a way, consciously and actively compiling the national economy, forming a system of togetherness and kinship in each of regulating and issuing permits in economic life. In other words, every business license and other permits relating to it must guarantee the licensee is bound to implement a system of togetherness and kinship. The goal is achieved, after the implementation of development in all fields together by the community and the government, with the emphasis being placed on the economic field along with the quality of human resources still rests on aspects of equity, growth and stability. In connection with economic problems, one of the goals of development is to achieve the ideals of the nation, namely the creation of a just and prosperous society. Prosperous 
just society is meant is the goal of Indonesia's economic development based on Economic Democracy. ${ }^{8}$

Indonesia is a country with the 4th largest population in the world, with approximately 260 million more inhabitants in Indonesia, with a very large population, Indonesia has a very large HR potential in terms of quantity. The total population of Indonesia, which reached more than 242.3 million people or equivalent to two-fifths of the total population of ASEAN in 2011, made Indonesia's position inevitably a concern for ASEAN countries. Indonesia's opportunity to compete is actually quite large, currently Indonesia is ranked 16th in the world for the size of the economy. The size of the economy is also supported by the proportion of the population of productive age and the growth of a large middle class. The positive outlook for the Indonesian economy is also supported by the improvement of Indonesia's investment rating by the world rating agency and Indonesia's inclusion in the fourth rank prospective des-tinations based on UNCTAD World Invest-ment report. The stronger fundamentals of the Indonesian economy can be seen when many countries are "uprooted" hit by the weakening of the global economy, the Indonesian economy can still be maintained to grow positively. ${ }^{9}$

Countries in Europe and America are slowly starting to shift from the conventional economic system to the Islamic economic system, they have found an appropriate way to overcome the economic crisis that has befallen their respective countries, namely Sharia Economic System. This system has succeeded in becoming a solution to the problem of injustice that arises due to the conventional economic system, it shows that Islam does bring good for all, not only for Muslims. Islamization in economics makes the existing economy more Islamic and fairer.

Sharia economic system has advantages both in terms of science and systems, in the professional world of Islamic economics is also very much needed by the market because it is in accordance with demand. In Islamic economics there is also what is called a profit sharing system, meaning that it is for risk. In a conventional bank, if the borrower goes bankrupt, the guarantee will be taken, the bank will not bother, but with the Islamic economic system, there will be a period of suspension.

Islamic economics is also a surefire solution to poverty alleviation, this system is considered very suitable for poverty alleviation programs, this is very appropriate because the poor are not seen as lazy, but as those who do not get access to a better life. Here in lies the difference between the Islamic and conventional economic systems. The Islamic economic system does not aim to accumulate as much wealth as possible. But, how a better life can be achieved together, the meaning is mutual help in the good between those who have excess property against those who need these assets.

Islamic economics has the principle of synergy of mutual help. In accordance with the word of God in Surah Al Maidah verse 2 which means:"And help you in doing good and piety, and do not help in committing sins and transgressions." This principle allows people who first achieve success can help each other. Cooperation like this can realize the progress of the Islamic ummah together. Sharia economic system will increasingly teach us to care for the people who need around us, both in material and non-material forms. The success that has been obtained by someone can not be said to be perfect if the siblings around him are still overcome by lack and even poverty. Therefore, be a person who is useful for others. The Prophet Muhammad said that means: "A person does not believe before he loves his brother as he loves himself" (HR. BukhariMuslim). In another hadith, it also says, which means: "As good as humans are useful for other humans".

Encouragement from all walks of life in Indonesia ranging from microeconomic zones to large businesses has greatly assisted the development of sharia economic growth in the State of Indonesia. One of them has been successful in terms of recognizing Islamic schemes. All of

8 Renny Supriyatni B, Loc.cit.

9 Ari Anggarani Winadi Prasetyoning Tyas, Vita Intan Safitri, Penguatan sektor UMKM sebagai strategi menghadapi MEA 2015, jurnal ekonomi Volume 5 Nomor 1, mei 2014. 
this must be supplemented by the support of equitable distribution of sharia economic socialization by non-governmental organizations in all regions of the country of Indonesia. In a source stated that the growth of Islamic financial institutions in Indonesia is predicted to be able to reach more than 50 percent in the coming year. That growth is not only in the banking world, but also in other Islamic financial institutions such as insurance and Islamic finance companies. Specifically for sharia insurance, future growth will be encouraged by the existence of a plan for drafting sharia insurance laws. ${ }^{10}$

The upcoming national legislation program needs to schedule and give priority to laws relating to Islamic Financial Institutions which are currently growing and developing. The drafting of the Law relating to the aforementioned areas can be initiated by both the government and the House of Representatives in accordance with the procedures and mechanisms and provisions in force.

The positivation effort itself has actually been going on for a long time, with the promulgation of the 1960 Agrarian Law, Law No. 1 of 1974 concerning Marriage Law, then increased to Islamic law as a source of national law in Law No. 7 of 2009 concerning Religious Courts, Presidential Instruction No. 1 of 1991 concerning the Socialization of Compilation of Islamic Law, Law No. 41 of 2004 concerning Endowments, the Zakat Law, the Hajj Law and most recently Law No. 3 of 2006 concerning Amendments to Law No. 7 of 1989 concerning Religious Courts (BAL) which provides for the expansion of material competencies for the Religious Courts, including in the Shariah economy. ${ }^{11}$

Observing the rapid development of Islamic economics both at global and local levels, in the context of the economic trends of the globalization era, a more directed and clear strategy is needed so that the Islamic economy will increasingly get a solid place in future economic development, so that soon an era of morality, justice, and godliness is realized. Based on the existing situation, the strategy of developing Islamic Economics at least needs to pay attention to two fundamental aspects, namely the conceptual/academic and implementative/practical aspects of Islamic economics. The development of conceptual aspects emphasizes the development of Islamic Economics as a science or system, while the development of implementative aspects emphasizes the development of Islamic economics that is applied to business institutions that apply Sharia principles in conducting their business. Both aspects should be developed together so that they are able to form an Islamic Economic System that can be used to explore the potential and ability of the community (the world and Indonesia) to build alternative economic systems as a substitute or complement of existing conventional economic systems.

Islamic economic development continues to be pursued by involving various parties both individually and institutionally. Thinkers continue to try to explore and discuss the Islamic economic system seriously and then inform the public through seminars, symposiums, book writing as well as through the internet and other media. On the part of the practitioners or relevant business actors also continue to improve and implement the Islamic economic system in accordance with sharia principles that are permitted in carrying out their business. Thus the development of the Islamic economy is expected to be in line between conceptual and business practices in accordance with the guidance that will eventually form an Islamic economic system that is truly in accordance with the basic principles of the Sharia outlined.

Economics is an integral part of Islamic teachings, and therefore Islamic economics will be realized only if Islamic teachings are fully believed and implemented. Islamic Economics studies the economic behavior of individuals who are consciously guided by Islamic teachings, the Koran and the Sunnah in solving the economic problems they face.

Islamic economics is an inseparable part of the concept of Islamic teachings. In Islam economic activities that are intended and intended for benefit are considered as worship. Therefore, studying Islamic economics and carrying out Islamic economic activities is a must for

$10 \mathrm{http} / /$ www.dakwatuna.com

${ }^{11}$ Abdul Mughits, Kompilasi Hukum Ekonomi Syari'ah, hlm 146 
Muslims. Whereas in the economic world there are several characteristics of Islamic economics, namely; ${ }^{12}$

a. The possessions of Allah and humans are caliphs of possessions.

b. Economics is bound by faith, sharia (law).

c. Balance between spirituality and materiality.

d. Individual freedom is guaranteed in Islam.

e. The state is authorized to interfere in the economy.

f. Consumption guidance.

g. Investment instructions.

h. Alms.

i. Prohibition of usury.

\section{CONCLUSION}

Several things related to the development of sharia economic law in Indonesia, between ideality and reality, it can be concluded that sharia economic law means Islamic economic law that is extracted from the Islamic economic system which is the implementation of fiqh in the economic field. The implementation of the economic system by the community requires the law to regulate in order to create an orderly law and resolve disputes that might arise in economic interactions. In reality Islamic economic law, until now is still a long process to arrive at the idealized form, while the development of Islamic economics is very rapid, with various models and shapes, this can be felt by our existence, so the government is greatly helped in running the wheels of the economy in Indonesia. Given the stretch and its relatively new development, while Indonesia's political will has not yet fully responded to this positive opportunity. Especially related to Islamic microfinance institutions. Each transaction will open the possibility of a dispute. Therefore, in handling disputes arising from banking or sharia economic transactions, the settlement is based on the provisions of the religious law, and resolved by a court that can represent the practice of religious teachings, namely the Religious Courts. The contribution of sharia economic law to economic development in Indonesia should be given facilities in the form of certainty in the form of regulations, the aim of which is to facilitate and develop sharia economics in Indonesia.

\section{SUGGESTION}

The government must be able to explore Islamic economic law with the aim of developing the economy in Indonesia, because its contribution can already be felt by the community directly. The trick is to make regulations that are the basis of economic development and development in Indonesia. For the community, there is no longer any doubt in using or conducting sharia-based economic transactions, because it will benefit the community itself. The benefits obtained are not only material, but get peace in the transaction and no less important to get blessings.

\section{REFERENCE}

${ }^{12}$ Rivai dan Buchari, Islamic Economics, hlm. 169. 


\section{BUKU}

Abdullah Kelib, Metode Penelitian Fiqh Dan Hukum Sekuler'dalam Majalah Masalah-Masalah Hukum, FH Undip No.5/1995, hlm. 5 dari pendapat Suharsini Harikunto, Prosedur Penelitian (satu pendekatan praktek), Jakarta: Rieneka Cipta, 1993.

Bustanudin Agus, Pengembangan Ilmu-Ilmu Sosial Studi Bidang Antara Pandangan Ilmiah Dan Ajaran Islam, Jakarta: Gema Insani, 1999.

Khudzaifah Dimyati, Teorisasi Hukum (Studi Perkembangan Pemikiran Hukum di Indonesia 1945-1990), Yogyakarta: Genta Publishing, 2010.

Soerjono Soekamto, Sri Marmudji, Penelitian Hukum Normatif: Suatu Tinjauan Singkat, Jakarta: PT. Raja Grafindo Persada, 2004.

Said Sa'ad Marathon, Ekonomi Islam Di Tengah Krisis Ekonomi Global, Maktabah Ar-Riyadh, Jakarta, 2007.

\section{JURNAL}

Ari Anggarani Winadi Prasetyoning Tyas, Vita Intan Safitri, Penguatan sektor UMKM sebagai strategi menghadapi MEA 2015, jurnal ekonomi Volume 5 Nomor 1, mei 2014.

\section{INTERNET}

http://www.dakwatuna.com 